\title{
Pharmacokinetics of Continuous Subcutaneous Insulin Infusion
}

\author{
T. Lauritzen, S. Pramming, T. Deckert and C. Binder \\ Steno Memorial Hospital and Hagedorn Research Laboratory, Gentofte, Denmark
}

\begin{abstract}
Summary. One of the reasons for the variability of blood glucose regulation in Type 1 (insulin-dependent) diabetic patients is the huge variation in subcutaneous absorption of intermediate-acting insulin. We have investigated the variation in insulin absorption during continuous subcutaneous insulin infusion in eight such patients. The content of insulin in the subcutaneous tissue was measured using ${ }^{125}$ I-labelled insulin. The concentration of free serum insulin and blood glucose was followed from $1 \mathrm{~h}$ before and from $7 \mathrm{~h}$ after breakfast on two consecutive days. The amount of insulin absorbed during $24 \mathrm{~h}$ differed in all cases by less than $3 \%$ from the daily insulin dose given by the pumps. Mean insulin absorption rates and mean free insulin concentration showed peak values $30-90 \mathrm{~min}$ after meal bolus injections; this was sufficient to maintain near-normal blood glucose. Mean free serum insulin correlated strongly with disappearance of insulin from the
\end{abstract}

subcutaneous tissue $(r=0.98)$. From the insulin absorption rates and free insulin concentrations during basal constant insulin infusion, the half-time of serum insulin was calculated as $6 \mathrm{~min}$. Compared with the known large variability in the absorption of intermediate-acting insulin, continuous subcutaneous insulin infusion offers a precise and reproducible way of insulin administration resulting in post-prandial serum insulin peaks sufficient to maintain near-normal blood glucose levels. The half-time of serum insulin during subcutaneous infusion corresponds to values for intravenous infusion given in the literature, indicating that local degradation of insulin in subcutaneous tissue is of minor importance.

Key words: Continuous subcutaneous insulin infusion, insulin absorption, half-time of insulin, local insulin degradation.
Conventional insulin therapy with one or two injections a day of a mixture of fast- and intermediate-acting insulin fails to normalize blood glucose in most Type 1 (insulin-dependent) diabetic patients. One reason for this is the inability of long- and intermediate-acting insulins to produce a constant basal insulin supply because of the considerable variation in the amount of insulin absorbed per $24 \mathrm{~h}$ [1], and the fact that peak plasma insulin concentrations seldom appear in relation to meals [2]. We therefore wanted to test whether the success of portable insulin infusion pumps in achieving near-normal blood-glucose regulation [3-5] is due to a reduction of the variability in the amount of insulin absorbed per $24 \mathrm{~h}$ and the appearance of reproducible post-prandial peak insulin concentrations.

\section{Patients and Methods}

Eight Type 1 diabetic patients (three males and five females, age 24-50 years) gave informed consent to be included in the study. They were randomly selected from patients with post-prandial C-peptide levels of $<0.06 \mathrm{nmol} / 1$. The test-meal contained $45 \%$ carbohydrate and comprised $40 \%$ of daily energy consumption. None had local lipodystrophies nor other diseases than diabetes. Details of the patients are given in Table 1.

Before the study, patients had been treated with continuous subcutaneous insulin infusion (CSII) for at least 1 week. The pumps used were the Mill-Hill 1001 HM or Auto-syringe AS-6C infusors. The infusion needle was placed in the subcutaneous tissue of the abdominal wall. The insulin used was highly purified pork soluble insulin (40 IU $/ \mathrm{ml}$, Velosulin). Sixteen hours before the study this insulin was substituted by a similarly formulated insulin containing $20 \%{ }^{125} \mathrm{I}$ monoiodinated porcine insulin [6] (specific radioactivity $10 \mu \mathrm{Ci}$ / $40 \mathrm{IU})$. After an overnight fast, the radioactivity above the infusion site was measured by external counting [7]. The results are expressed in counts per min after correction for background activity. Background activity was measured as the activity over that part of the cannula and needle which was in the field of the detector during the study. Evaluation of this procedure was done by measuring the activity over a depot of 4 IU with and without the 'butterfly' needle in situ. The activity measured over the insulin depot with the 'butterfly' in situ minus the background activity measured as described above revealed $99.4 \% \pm 2.0 \%$ (mean $\pm \mathrm{SEM}$ ) of the activity measured over the depot without the needle in situ. This means that the part of the insulin depot which might be hidden for the detector by the metal needle is negligible. Measurement of the activity over the depot and blood-sam- 
Table 1. Clinical data of the eight Type 1 diabetic patients

\begin{tabular}{|c|c|c|c|c|c|c|c|}
\hline $\begin{array}{l}\text { Case } \\
\text { number }\end{array}$ & $\begin{array}{l}\text { Age } \\
\text { (years) }\end{array}$ & Sex & $\begin{array}{l}\text { Duration of insulin } \\
\text { treatment (years) }\end{array}$ & $\begin{array}{l}\text { Duration of CSII } \\
\text { treatment }^{2}\end{array}$ & $\begin{array}{l}\text { Insulin dose } \\
\text { (IU } / 24 \mathrm{~h} \text { ) }\end{array}$ & $\begin{array}{l}\text { Percent binding to } \\
\text { insulin antibodies [10] }\end{array}$ & $\begin{array}{l}\text { Percent of ideal body } \\
\text { weight }\end{array}$ \\
\hline 1 & 33 & $\mathrm{~F}$ & 18 & 7 days & 44 & 2.5 & 110 \\
\hline 3 & 31 & M & 8 & 15 months & 36 & 2.3 & 97 \\
\hline 4 & 24 & $F$ & 15 & 15 months & 29 & 4.2 & 100 \\
\hline 5 & 40 & $\mathbf{F}$ & 26 & 13 months & 33 & 7.3 & 84 \\
\hline 6 & 31 & $F$ & 16 & 14 months & 37 & 2.1 & 90 \\
\hline
\end{tabular}

CSII $=$ Continuous subcutaneous insulin infusion

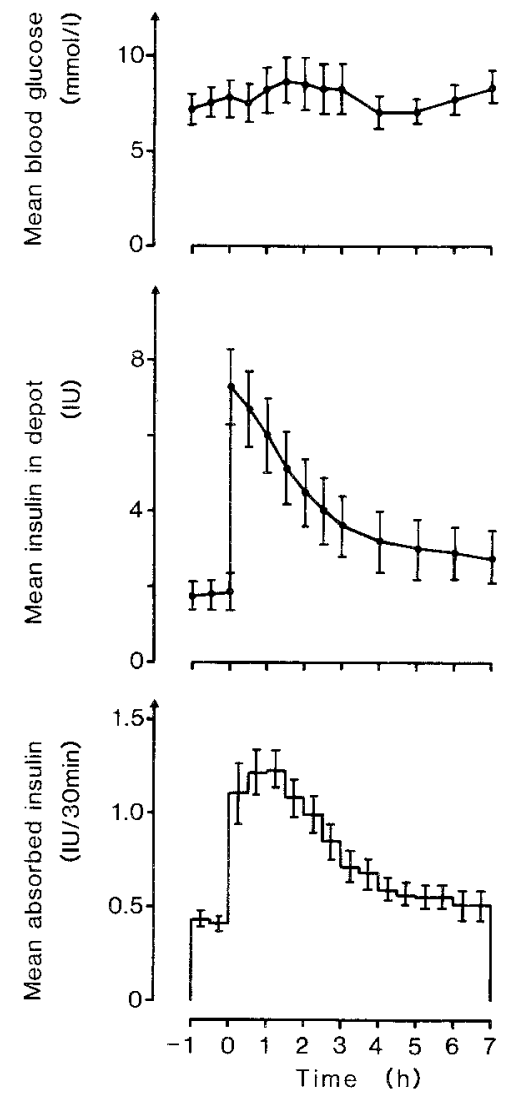

Fig. 1. Blood glucose, amount of insulin in the subcutaneous depot and insulin absorption rate in eight Type 1 diabetic patients. Results are mean \pm SEM. Basal insulin infusion was continued throughout the study period and an additional meal bolus injection was given through the pump at time 0 . Breakfast was served immediately after the meal bolus injection

pling for blood glucose and serum free insulin were carried out at $-60,-30,0,30,60,90,120,150,180,240,300,360$, and 420 min after a meal bolus injection of 5.5 IU (range 3.3-9.1 IU) given through the pump. The constant insulin infusion was continued throughout the study with a mean rate of $0.9 \mathrm{IU} / \mathrm{h}$ (range $0.7-1.5$ ). Breakfast (composition as the test meal described above) was served immediately after the bolus injection, and was the only food served during the study period, except for correction of hypoglycaemic episodes. After the last blood sample at $420 \mathrm{~min}$, patients received lunch with their usual lunch meal bolus as unlabelled soluble insulin. One hour later they changed again to labelled insulin when resiting the infusion needle.
Next morning the procedure from -60 to $420 \mathrm{~min}$ was repeated. Patients were given a solution of potassium iodide before and during the study to prevent accumulation of radioactivity in the thyroid.

Free serum insulin was measured as follows: $400 \mu \mathrm{l}$ serum $+25 \mu \mathrm{l}$ Hepes buffer ( $\mathrm{pH} 7.4$ ) were pre-incubated for $2 \mathrm{~h}$ at $37^{\circ} \mathrm{C}$. Then $30 \%$ polyethylene glycol $(425 \mu \mathrm{l})$ was admixed. After centrifugation, $100 \mu \mathrm{l}$ of the supernatant was mixed with a $10^{5}$-fold dilution of anti-insulin guinea pig serum (GP 115) in $0.04 \mathrm{~mol} / 1$ phosphate buffer ( $\mathrm{pH} 7.4$ ) containing $1 \%$ human albumin, $0.9 \% \mathrm{NaCl}$ and $0.01 \mathrm{~mol} / 1 \mathrm{EDTA}$. After $24 \mathrm{~h}$ of incubation at $4{ }^{\circ} \mathrm{C}, 100 \mu{ }^{125} \mathrm{I}-\mathrm{A}_{14}$-monoiodoinsulin (Spec. Act. approximately $250 \mu \mathrm{C} / \mu \mathrm{g}$ ), dissolved in buffer, was added before further incubation for $16-20 \mathrm{~h}$ at $4{ }^{\circ} \mathrm{C}$. Separation of bound from free insulin was carried out by adding $200 \mu \mathrm{l}$ of rabbit anti-guinea pig $\operatorname{IgG}$ (Dako, Copenhagen, Denmark, Z 108) and $38.9 \mathrm{ml}$ of $7.4 \%$ polyethylene glycol 6000 (PEG) in buffer containing 0.1\% Tween 20 (MerckSchuchardt, München, FRG). After $2 \mathrm{~h}$ of incubation at $4^{\circ} \mathrm{C}$ the centrifuged precipitate $(5000 \mathrm{~g})$ was washed and counted. Standards were dissolved in $0.04 \mathrm{~mol} / 1$ phosphate buffer containing $6 \%$ human albumin and $1.2 \%$ bovine $\gamma$-globulin (Cohn fraction II, Sigma, St. Louis, USA). The detection limit was $9 \mathrm{pmol} / 1(1.25 \mathrm{mU} / 1)$. The combined within-assay coefficient of variation $(\mathrm{CV})$ averaged $2.9 \%$, based on triplicates. The between-assay variation was related to concentration of insulin, being less than $10 \%(\mathrm{CV})$ for levels above $70 \mathrm{pmol} / 1$ $(10 \mathrm{mU} / 1)$ and increasing for lower levels. All samples from one patient were measured in the same assay.

The method used to measure insulin binding to antibodies has been described earlier [10]. The upper limit of the normal range is $4 \%$ $($ mean $+4 \mathrm{SD})$.

\section{Calculations}

The counts per $\min (\mathrm{cpm})$ at the subcutaneous injection site were transformed to IU insulin knowing that the increase in cpm immediately after bolus injection corresponded to the size of the bolus injection in IU. The insulin absorbed during any given period $t_{1}$ to $t_{2}$ was calculated as the difference in the size of the depot at time $t_{1}$ and $t_{2}$ plus the amount of insulin infused during that period. The insulin absorption rate was then calculated by dividing the absorbed amount of insulin in a given period with the duration of the period. The half-time $\left(t_{1 / 2}\right)$ of insulin in serum was calculated during basal infusion ( -60 to 0 min) using the formula $t_{1 / 2}=\frac{C_{p} \times V_{d}}{1.44 \times A_{r}}[8], C_{p}$ being the mean free insulin concentration during basal infusion, $V_{d}$ the distribution volume for insulin $(0.146 \mathrm{ml} / \mathrm{g}[9])$, and $A_{r}$ the calculated insulin absorption rate during basal infusion.

Results are given as mean and range. Coefficients of variation for the day-to-day difference were calculated as the standard deviation for the day-to-day differences divided by the mean. Non-parametric statistics have been used except for regression analysis. 
Table 2. Coefficient of variation for the day-to-day difference in the size of the depot in eight Type 1 diabetic patients

\begin{tabular}{|c|c|c|c|c|c|c|c|c|c|c|c|c|c|}
\hline & \multicolumn{13}{|c|}{ Time (min) } \\
\hline Coefficient of variation $(\%)$ & 36 & 38 & 27 & 10 & 13 & 16 & 20 & 23 & 22 & 24 & 24 & 24 & 27 \\
\hline
\end{tabular}

Table 3. Coefficient of variation for the day-to-day difference in absorbed amount of insulin in eight Type 1 diabetic patients

\begin{tabular}{llllllllllllllll}
\hline & Periods (min) \\
\cline { 2 - 12 } & $-60--30$ & $-30-0$ & $0-30$ & $30-60$ & $60-90$ & $90-120$ & $120-150$ & $150-180$ & $180-210$ & $240-270$ & $300-330$ & $360-390$ \\
\hline $\begin{array}{l}\text { Coefficient of } \\
\text { variation (\%) }\end{array}$ & 35 & 31 & 29 & 17 & 19 & 17 & 13 & 18 & 11 & 22 & 14 & 16 & \\
\hline
\end{tabular}

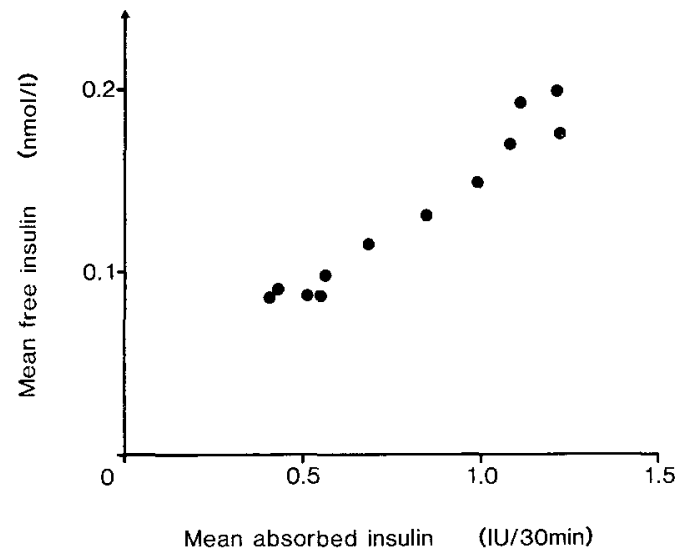

Fig. 2. The correlation between mean absorbed insulin in eight Type 1 diabetic patients during each 30 -min period and mean free serum insulin by the end of each period, $r=0.98$ ( $99 \%$ significant limits $0.91-1.00$ )

\section{Results}

Blood glucose was kept near normal throughout the study period (Fig.1). No significant increase in blood glucose was seen in relation to breakfast.

\section{Subcutaneous Insulin Depot}

The insulin depot during basal rate infusion averaged 1.8 IU (range 0.8-4.7 IU) (Fig. 1) with a day-to-day difference within patients from 0.1 to $1.2 \mathrm{IU}(\mathrm{CV}=$ $27-36 \%$, Table 2 ). Immediately after the meal bolus injection insulin in the depot averaged 7.3 IU (range 4.1-11.1 IU) with a day-to-day difference within patients ranging from 0 to $1.1 \mathrm{IU}(\mathrm{CV}=10 \%)$. Thereafter the content of insulin in the depot steadily declined. Seven hours after the meal bolus injection, the content of insulin in the depot had not reached the basal level $(p<0.01)$. During the $7 \mathrm{~h}$ following the meal bolus injection the CV for the day-to-day difference within patients gradually increased from 10 to $27 \%$.

\section{Insulin Absorption Rate}

The insulin absorption rate during basal infusion was $0.42 \mathrm{IU} / 30 \mathrm{~min}$ (range $0.18-0.65 \mathrm{IU} / 30 \mathrm{~min}$; Fig. 1) with a day-to-day difference within patients ranging from 0 to $0.37 \mathrm{IU} / 30 \mathrm{~min}(\mathrm{CV}=31-35 \%$, Table 3$)$. The mean insulin absorption rate was maximal 30-90 min after the meal bolus injection. Seven hours later the mean insulin absorption rate was still increased by $20 \%$ compared with the absorption rate during basal insulin infusion $(p<0.05)$. During the $7 \mathrm{~h}$ after meal bolus injection the $\mathrm{CV}$ for the day-to-day difference within patients ranged from 11 to $35 \%$.

The insulin absorbed during the first study day (IU/ $24 \mathrm{~h}$ ) differed in all patients by less than $2.8 \%$ from the amount of insulin given by the pumps during the day.

\section{Free Serum Insulin}

The mean free insulin in serum correlated closely with the mean insulin absorption rate $(r=0.98,99 \%$ significant limits $0.91-1.00$, Fig. 2), and showed peak values $30-90 \mathrm{~min}$ after the meal. The free insulin concentration showed day-to-day variations within patients with a mean CV of $24 \%$ (range $12 \%-42 \%$ ).

\section{Serum Insulin Half-time}

The mean serum half-time $\left(t_{1 / 2}\right)$ during basal insulin infusion was $6.1 \mathrm{~min}$. One patient with low binding to insulin antibodies and a very high free insulin concentration during basal insulin infusion $(0.2 \mathrm{nmol} / 1)$ had a half-life of $14.9 \mathrm{~min}$, the others ranging from 3.3 to $7.1 \mathrm{~min}$.

\section{Discussion}

With intermediate-acting insulin the daily amount of insulin absorbed varies from \pm 10 to $\pm 52 \%$ of the daily injected insulin dose. This variation explains up to $80 \%$ of the day-to-day variation in blood glucose concentration [1]. In the present study, patients changed to la- 
belled insulin $16 \mathrm{~h}$ before measurement of the morning insulin depot. This is sufficient time for all previous unlabelled fastacting insulin to be absorbed. Therefore we could calculate the amount of insulin absorbed during the $24 \mathrm{~h}$ between the two consecutive measurements of the morning insulin depot. This differed in all patients by less than $2.8 \%$ from the daily dose given by the pumps. This small variation may be one of the reasons why pump-treated patients show smaller day-to-day variation in blood glucose than patients treated with intermediate-acting insulin.

Another reason for better glycaemic control with the insulin pumps is the appearance of reproducible maximal insulin absorption rates and free serum insulin concentrations within $30-90 \mathrm{~min}$ after meal bolus injections. This is sufficient to maintain blood glucose at near-normal values post-prandially. With conventional treatment well-defined post-prandial serum insulin peaks are seldom seen [2].

The strong correlation between the disappearance of insulin from the subcutaneous insulin depot and the appearance of insulin in serum, together with a calculated half-time of insulin in serum equal to values found by others during intravenous infusion of insulin [8], indicates that local degradation of insulin in the subcutaneous tissue, if present, is small and constant with only minor clinical implications. Similar results have been found for NPH insulin [10].

The absorption of the subcutaneous bolus injection given through the pump follows the same absorption pattern as seen after subcutaneous injection of soluble insulin given through a syringe [7].

In conclusion, insulin pumps delivering insulin into the subcutaneous tissue offer a precise and reproducible way of insulin administration resulting in postprandial serum insulin peaks sufficient to maintain near-normal blood glucose levels. Furthermore, local degradation of insulin in the subcutaneous tissue, if present, is small and constant and has little clinical relevance.

Acknowledgements. We thank the patients for their collaboration and B. Hansen und S. Linde, Hagedorn Research Laboratory for prepar- ing the iodinated insulin preparations. This study was supported by grants from Danmarks Sundheds Fond and the Danish Medical Concil.

\section{References}

1. Lauritzen T, Faber OK, Binder C (1979) Variation in ${ }^{125}$ I-insulin absorption and blood glucose concentration. Diabetologia 5: 291-295

2. Molnar CD, Taylor WF, Langworthy AL (1972) Plasma immunoreactive insulin patterns in insulin-treated diabetics. Studies during continuous blood glucose monitoring. Mayo Clinic 47: $709-719$

3. Lauritzen T, Frost-Larsen K, Svendsen P Aa, Larsen H-W, Deckert T, Christiansen JS, Parving H-H, Binder C, Nerup J, Deckert M, Larsen A, Lorup B, Bojsen J, Bech-Jansen L (1982) Effect of 6 months of strict metabolic control on eye and kidney function in insulin-dependent diabetics with background retinopathy. Lancet 1: $121-124$

4. Lauritzen T, Deckert T, Svendsen P Aa, Larsen H-W, Frost-Larsen K, Christiansen JS, Parving H-H, Binder C, Nerup J, Deckert M, Larsen A, Lørup B, Bojsen J, Bech-Jansen L (1982) One year's experience of insulin pumps in diabetes. Nordisk Medicin 97: 130-133 (in English)

5. Pickup JC, White MC, Keen H, Parsons JA, Alberti KGMM (1979) Long-term continuous subcutaneous insulin infusion in diabetics at home. Lancet 2: 870-873

6. Hansen B, Linde S, Kølendorf K, Jensen F (1979) Absorption of protamine-insulin in diabetes. I. Preparation and characterization of protamine- ${ }^{125}$ I-insulin. Horm Metab Res 11: $85-90$

7. Binder C (1969) Absorption of injected insulin. Acta Pharmacol Toxicol (Suppl 2) 27:1-84

8. Mayer SE, Melmon KL, Gilman AG (1980) Introduction; the dynamics of drug absorption, distribution and elimination. In: Goodman GS, Gilman AG, Gilman A (eds) The pharmacological basis of therapeutics, 6th edn. Macmillan, New York, pp $21-27$

9. Frost DP, Srivastava MC, Jones RH, Nabarro JDN, Sonksen PH (1973) The kinetics of insulin metabolism in diabetes. Postgrad Med J (Suppl 49): 949-954

10. Lauritzen T, Pramming S, Gale EAM, Deckert T, Binder C (1982) The absorption of NPH insulin and its clinical implications. $\mathrm{Br}$ Med J 285: 159-162

Received: 17 August 1982

and in revised form: 10 December 1982

Dr. T. Lauritzen

Steno Memorial Hospital

DK-2820 Gentofte

Denmark 